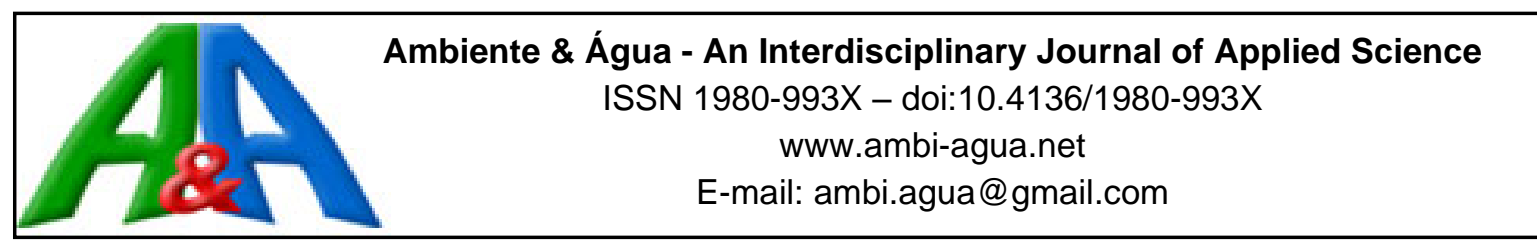

\title{
Evaluation of the cytotoxic and genotoxic potential of waters of the Paraíba do Sul River Basin - RJ through the Allium cepa test system
}

\author{
ARTICLES doi:10.4136/ambi-agua.2521
}

Received: 22 Jan. 2020; Accepted: 08 May 2020

\author{
Emanoelly Barbosa Sacramento ${ }^{D}$; Caroline de Almeida Azevedo $\oplus^{D}$; \\ Saulo Tavares Abreu ${ }^{\circledR}$; Helcio Resende Borba ${ }^{\circledR}$; Viviane Moreira de Lima* \\ Instituto de Ciências Biológicas e da Saúde. Departamento de Biologia Animal. Universidade Federal Rural do \\ Rio de Janeiro (UFRRJ), Rodovia BR 465, Km 07, S/N, CEP: 23890-000, Seropédica, RJ, Brazil. \\ E-mail: emanoellysacramento@ hotmail.com, carolineaazevedo10@gmail.com, \\ abreu.saulo.st@gmail.com, borbahr4@gmail.com \\ "Corresponding author. E-mail: vilima@ufrrj.br
}

\section{ABSTRACT}

The public water supply of the Rio de Janeiro metropolitan region is highly dependent on transposition from the Paraíba do Sul River: $70 \%$ of the water is diverted to the Piraí River and then passes through a series of other rivers and reservoirs, finally discharging in the Guandu River. During this path, the water is exposed to many sources of pollution. This makes the quality of the raw water that reaches the Guandu Treatment Station (WTS) highly vulnerable. This article reports the analysis of the cytogenotoxic potential of water samples collected at four different points along the Piraí River downstream from the transposition point, utilizing the Allium cepa test system. The samples were collected in two periods, the dry and wet seasons. The water at all four collection points presented some level of cytogenotoxicity, with the presence in the test cells of large nucleoli, multiple nucleoli, nuclear buds, lagging chromosomes, sticky chromosomes, karyorrhexis, cytoplasmic shrinkage and changes of the mitotic index. The samples collected during the dry season had a larger number of cells with alterations, indicating that the cytogenotoxic potential varies in function of the time of year, depending on the volume of contaminated effluents. The results obtained along with data from the Rio de Janeiro State Environmental Institute (INEA) for the same period reveal the importance of monitoring along with proper sanitation and sewage treatment, and that the presence of pollutants not only hampers water treatment, but also poses risks to organisms at different trophic levels, including humans.

Keywords: bioindicator, cytogenotoxicity, water quality.

\section{Avaliação do potencial citotóxico e genotóxico de águas da Bacia do rio Paraíba do Sul-RJ através do sistema teste Allium cepa}

\section{RESUMO}

O abastecimento público da região metropolitana do Rio de Janeiro é bastante dependente da transposição do rio Paraíba do Sul: $70 \%$ de suas águas são desviadas para o rio Piraí e através de uma série de reservatórios, descarregadas no rio Guandu. Neste trajeto ocorre a exposição a diversas fontes de poluição, o que coloca a qualidade da "água bruta" da Estação de Tratamento de Águas do Guandu (ETA) sob grande vulnerabilidade. O intuito do trabalho foi analisar o 
potencial citogenotóxico de águas coletadas em quatro diferentes pontos do rio Piraí, a jusante da transposição, utilizando o sistema teste de Allium cepa. As coletas foram realizadas em duas épocas distintas, uma no período de estiagem e outra no período chuvoso. Todos os pontos estudados apresentaram algum nível de citogenotoxicidade, com a presença de nucléolos grandes, nucléolos múltiplos, brotos nucleares, cromossomos em atraso, aderência cromossômica, células com cariorréxe, retrações citoplasmáticas e alterações no índice mitótico. As amostras coletadas durante a estação seca apresentaram um número maior de alterações indicando que o potencial citogenotóxico varia em função do tempo, dependendo do aumento da emissão de efluentes contaminados. Os resultados obtidos aliados aos dados do Instituto Estadual do Ambiente (INEA) no mesmo período, ressaltam a importância de serviços de monitoramento, saneamento, tratamento de esgoto e que a presença de poluentes não só inviabiliza a tratabilidade da água, mas traz riscos reais aos organismos de diferentes níveis tróficos, incluindo o homem.

Palavras-chave: bioindicador, citogenotoxicidade, qualidade da água.

\section{INTRODUCTION}

The Paraíba do Sul River originates in the state of São Paulo with the confluence of the Paraibuna and Paraitinga Rivers, passes through the entire Paraíba Valley and traverses the state of Rio de Janeiro before emptying into the Atlantic Ocean in the municipality of São João da Barra, flowing for more than 1,100 Km (Marengo and Alves, 2005).

Although most of the water consumed in the Rio de Janeiro metropolitan region comes from the Guandu River, much of that volume originates from the Paraíba do Sul River, through transposition, first into the Santa Cecília Reservoir in the municipality of Barra do Piraí (RJ), where there is a pumping station that diverts the water to the Piraí River. In this region alone, the Paraíba do Sul River contributes to the supply of some 9 million people (CBH Guandu, 2015; Demanboro, 2015).

The river is currently in a critical ecological state, due to the discharge of untreated domestic and industrial effluents along with agricultural waste (Oliveira et al., 2011). Since the state of Rio de Janeiro is the downstream user of the water from the Paraíba do Sul River, it is completely vulnerable to pollution and interferences caused by upstream users, in addition to the effects of human activities that occur in the state itself (INEA, 2010).

The presence of pollutants can prevent the development of many organisms, compromising the food chain, besides affecting the health of the population, since industrial, domestic and agricultural wastes contain compounds that variously have mutagenic, cytotoxic and/or genotoxic potential that are often not eliminated during the treatment process (Nielsen and Rank, 1994; Oliveira et al., 2011; Kasper et al., 2018).

Therefore, the objective of this study was to analyze the water from the Paraíba do Sul River regarding the presence of pollutants with cytogenotoxic potential, using the Allium cepa test system as a bioindicator.

\section{MATERIALS AND METHODS}

\subsection{Collection sites}

Water samples were collected at four points of the Piraí River, downstream from the transposition of the Paraíba do Sul River, which occurs in the municipality of Barra do Piraí. The points were chosen randomly, with distance of approximately $2 \mathrm{Km}$ apart, at the following

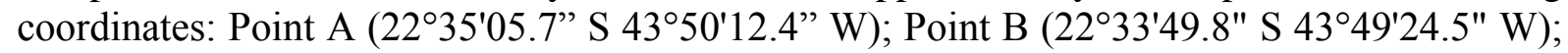
Point C $\left(22^{\circ} 33^{\prime} 06.3^{\prime \prime} \mathrm{S} 4^{\circ} 49^{\prime} 05.0^{\prime \prime} \mathrm{W}\right)$; and Point D $\left(22^{\circ} 32^{\prime} 14.9^{\prime \prime} \mathrm{S} 43^{\circ} 48^{\prime} 59.6^{\prime \prime} \mathrm{W}\right)$ 
(Figure 1). The collections were performed in the dry season (July 2017) and rainy season (March 2018).

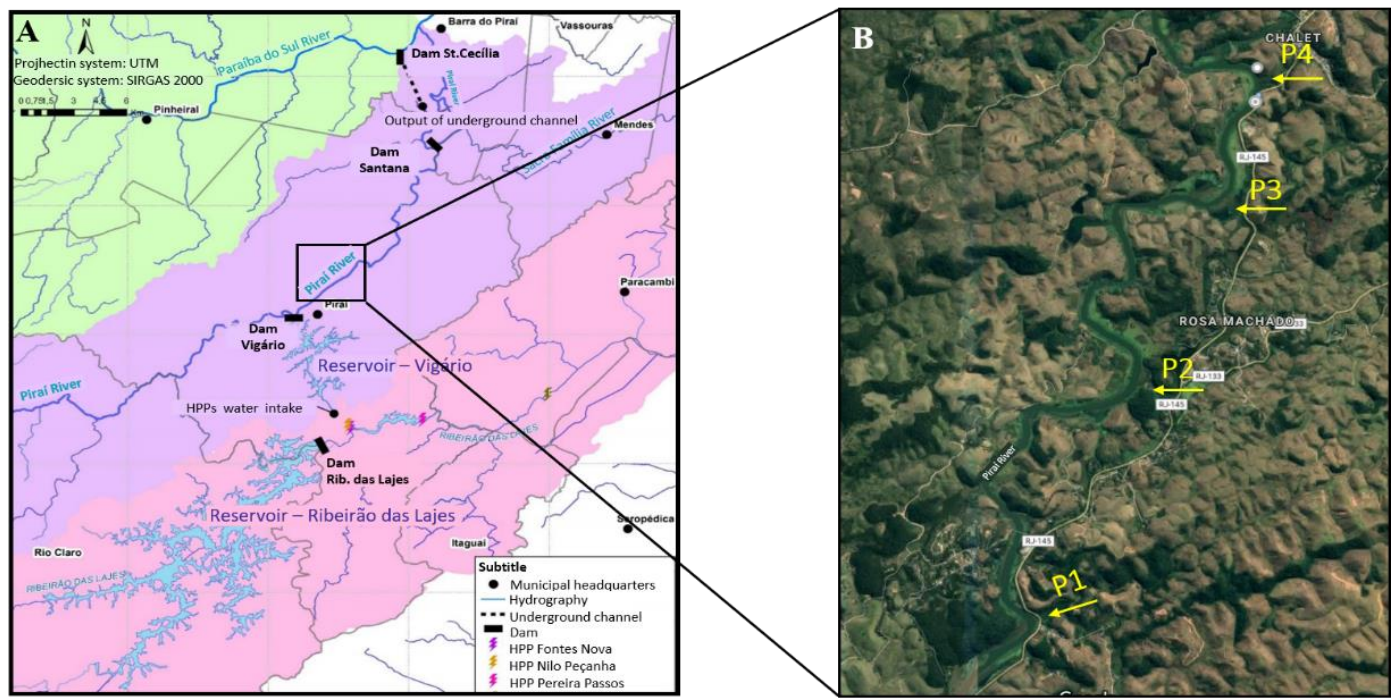

Figure 1. Collection sites. A - Main elements of the system for transposition of the Paraíba do Sul River to the Piraí, Ribeirão das Lajes and Guandu Rivers. Source: Adapted from CBH Guandu (2015). B - Geographic location of the collection points in Piraí River after transposition of Paraíba do Sul River at the Santa Cecília Reservoir in the state of Rio de Janeiro.

\subsection{Samples collection}

Samples from each site were collected in a $10 \mathrm{~L}$ bucket and transferred to polyethylene flasks $(1 \mathrm{~L})$ that were properly identified and kept in coolers with ice for transport to the laboratory, where they were kept at $-20^{\circ} \mathrm{C}$ for further genotoxicity and cytotoxicity analysis.

\subsection{Cytotoxicity and genotoxicity}

Commercially acquired organic cultured onion bulbs approximately $2.0 \mathrm{~cm}$ in diameter were used in the test. A stylet was used to remove the external cataphyll from each bulb without damaging the root buds. Five bulbs were used for water samples from each point, as well as positive and negative controls. Initially, the bulbs were placed in a container with distilled water for 48 hours, with daily water exchanges. The bulbs were then transferred to tubes containing water samples collected at the sites previously mentioned, where they remained for 48 hours. The bulbs used as negative controls were kept in distilled water and the positive ones were placed in an ethyl methane sulfonate (EMS, $25 \mathrm{mM}$ ) solution. The test and the control bulbs were incubated at $25^{\circ} \mathrm{C}$ with daily water exchanges. For each treatment, root tips, between 2 and $2.5 \mathrm{~cm}$ in length, were removed from the bulbs after 48 hours of exposure to the respective solutions and used to prepare slides according to the method described by de Castro and Sousa et al. (2017), with some modifications. Five root tips were removed from each bulb and fixed in an ethanol: glacial acetic acid solution at 3:1 (V/V) and stored at $4^{\circ} \mathrm{C}$ until the moment of preparing the slides. Five slides were prepared for each bulb, using five different root tips (one slide for each). The root tips were washed with distilled water twice for 5 minutes, hydrolyzed in $\mathrm{HCl} 5 \mathrm{~N}$ for $30 \mathrm{~min}$, washed again twice in distilled water for 5 minutes and then placed on the slides with tweezers. The subapical meristems were fragmented with a scalpel, stained with $2 \%$ acetic orcein, and covered with a coverslip.

All slides were coded and evaluated under an Olympus BX binocular optical microscope with $100 \mathrm{X}$ magnification. The parameters used to determine the genotoxic and cytotoxic potential of the samples were the presence of chromosome and cell alterations as well as changes in the mitotic index. A total of 1,000 cells were analyzed per bulb, or 5,000 cells for 
each group. With the exception of the mitotic index, expressed as a percent, the results are expressed in absolute terms. The most frequent anomalies are shown in the micrographs.

\subsection{Statistical design}

The data were analyzed by the Chi-square $\left(\chi^{2}\right)$ test with probability $<0.05$, using Yates correction, employing the Bioestat. 5.0 program.

\section{RESULTS AND DISCUSSION}

The public water supply of the Rio de Janeiro metropolitan region relies heavily on transposition of water from the Paraíba do Sul River, which occurs at the Santa Cecília Reservoir in Barra do Piraí. Through this transposition, $70 \%$ of the water from the Paraíba do Sul River is diverted to the Piraí River, and then through a series of other reservoirs until finally being discharged into the Guandu River. The resulting total volume from these rivers enables supplying more than $80 \%$ of the water in the Rio de Janeiro metropolitan region, serving some 9 million people (CBH Guandu, 2015; Demanboro, 2015). During its flow through the basins of the Paraíba do Sul, Piraí and Ribeirão das Lajes/Guandu Rivers, the raw water that supplies the Guandu Water Treatment Station (WTS) is exposed to many sources of pollution, including untreated domestic and industrial (including mining) wastes, agricultural runoff, leaching from landfills and trash dumps, and runoff from highways and railways, besides potential environmental accidents. This makes the raw water quality of the Guandu WTS highly vulnerable (CBH Guandu, 2015).

The water samples analyzed in this study were collected at four points along a stretch of the Piraí River located in Barra do Piraí, downstream from the transposition point of the Paraíba do Sul River. The samples from all these points presented some level of cytogenotoxicity, with observation of the presence of cells with large nucleoli, multiple nucleoli, nuclear buds, lagging chromosomes, sticky chromosomes, karyorrhexis and cytoplasmic shrinkage (Figure 2; Tables 1 and 2).

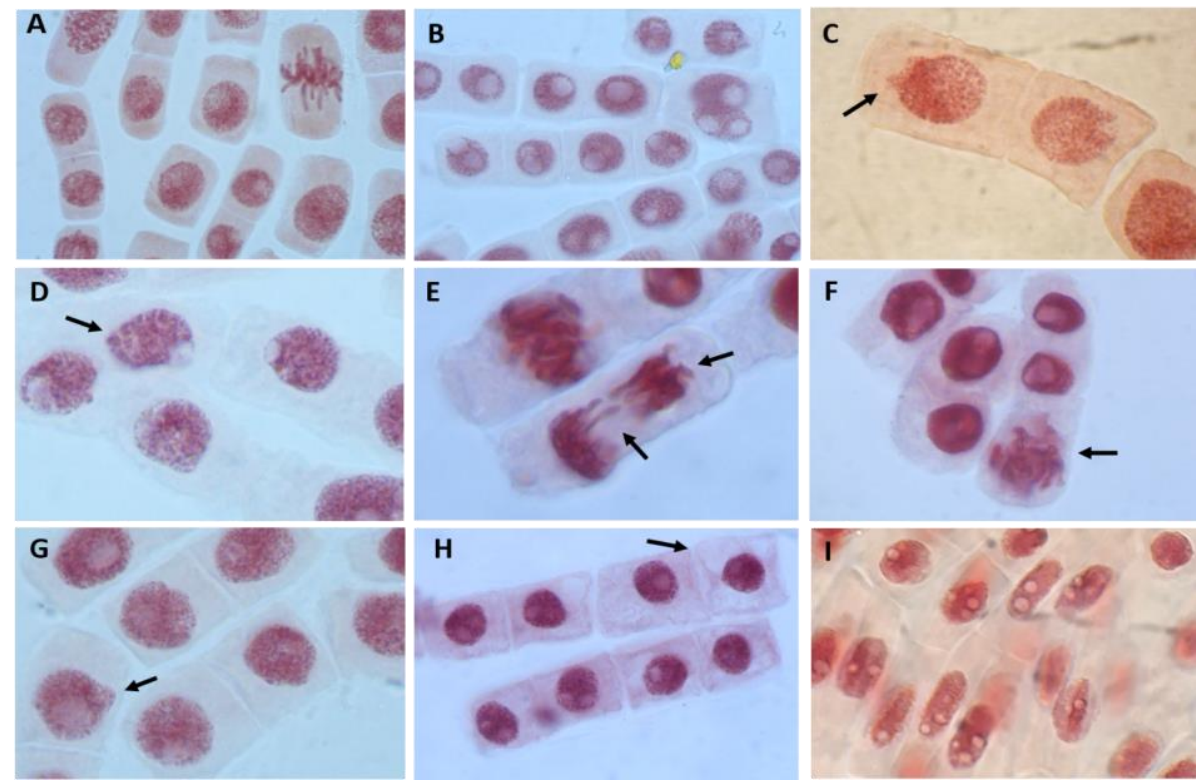

Figure 2. Allium cepa meristematic cells exposed to ethyl methane sulfonate (EMS) and water samples collected at different sites. (a-i); (a) normal cells; (b) large nucleoli; (c) nuclear bud (arrow); (d) karyorrhexis (arrow); (e) lagging chromosomes (arrows); (f) sticky chromosomes (arrows); (g) large nucleoli and nuclear bud (arrow); (h) cytoplasmic shrinkage (arrow); (I) multiple nucleoli. 
Table 1. Cells changes and mitotic index in A. cepa roots submitted to different treatments during the dry season.

\begin{tabular}{lcccccccccc}
\hline Treat. & Conc. & LN & NB & LNB & KLN & K & SC & LC & CK & MI (\%) \\
\hline NC & $\mathrm{dH}_{2} \mathrm{O}$ & $836^{(\mathrm{f})}$ & $33^{(\mathrm{d})}$ & $9^{(\mathrm{e})}$ & $23^{(\mathrm{b}, \mathrm{d})}$ & $8^{(\mathrm{d})}$ & $2^{(\mathrm{c})}$ & $1^{(\mathrm{e})}$ & $0^{(\mathrm{c})}$ & $4.56^{(\mathrm{b})}$ \\
EMS & $25 \mathrm{mM}$ & $3370^{(\mathrm{a})}$ & $129^{(\mathrm{a})}$ & $227^{(\mathrm{a})}$ & $0^{(\mathrm{e})}$ & $27^{(\mathrm{a}, \mathrm{b})}$ & $55^{(\mathrm{a})}$ & $15^{(\mathrm{a})}$ & $9^{(\mathrm{b})}$ & $2.78^{(\mathrm{c})}$ \\
PA & & $\mathbf{1 8 4 9}^{(\mathrm{b})}$ & $\mathbf{1 0 6}^{(\mathrm{a}, \mathrm{b})}$ & $\mathbf{2 2}^{(\mathrm{c}, \mathrm{d})}$ & $15^{(\mathrm{b}, \mathrm{c})}$ & $\mathbf{1 8}^{(\mathrm{b}, \mathrm{c})}$ & $\mathbf{1 0}^{(\mathrm{b})}$ & $2^{(\mathrm{c}, \mathrm{d}, \mathrm{e})}$ & $0^{(\mathrm{c})}$ & $\mathbf{5 . 7 5}^{(\mathrm{a})}$ \\
PB & & $\mathbf{1 6 3 8}^{(\mathrm{d})}$ & $\mathbf{7 6}^{(\mathrm{c})}$ & $13^{(\mathrm{d}, \mathrm{e})}$ & $9^{(\mathrm{c})}$ & $\mathbf{3 3}^{(\mathrm{a})}$ & $\mathbf{1 0}^{(\mathrm{b})}$ & $6^{(\mathrm{b}, \mathrm{e})}$ & $4^{(\mathrm{b}, \mathrm{c})}$ & $4.64^{(\mathrm{b})}$ \\
PC & & $\mathbf{1 7 3 3}^{\mathrm{c}(\mathrm{c})}$ & $\mathbf{1 2 4}^{(\mathrm{a})}$ & $\mathbf{3 4}^{(\mathrm{c})}$ & $32^{(\mathrm{a}, \mathrm{d})}$ & $\mathbf{3 7}^{(\mathrm{a})}$ & $4^{(\mathrm{b}, \mathrm{c})}$ & $3^{(\mathrm{b}, \mathrm{e})}$ & $0^{(\mathrm{c})}$ & $\mathbf{6 . 2}^{(\mathrm{a})}$ \\
PD & & $\mathbf{1 4 9 5}^{(\mathrm{e})}$ & $\mathbf{9 0}^{(\mathrm{b}, \mathrm{c})}$ & $\mathbf{6 6}^{(\mathrm{b})}$ & $\mathbf{3 9}^{(\mathrm{a})}$ & $\mathbf{2 7}^{(\mathrm{a}, \mathrm{c})}$ & $3^{(\mathrm{b}, \mathrm{c})}$ & $\mathbf{1 0}^{\mathrm{a}, \mathrm{b})}$ & $\mathbf{3 4}^{(\mathrm{a})}$ & $4.42^{(\mathrm{b})}$ \\
\hline
\end{tabular}

(a), (b), (c), (d) (e) and (f) different letters in the same column differ from each other $(\mathrm{P}<0.05)$ according to the $\chi^{2}$ test; Treat - treatment; NC - negative control; EMS - positive control; PA point A; PB - point B; PC - point C; $\mathbf{P D}$ - point D; $\mathbf{d} \mathbf{H}_{2} \mathbf{O}$ - distilled water; $\mathbf{L N}$ - one or more large nucleoli; NB - nuclear bud; LNB - large nucleoli and nuclear bud; KLN - karyorrhexis and large nucleoli; K - karyorrhexis; SC - sticky chromosomes; LC - lagging chromosome; $\mathbf{C K}$ - cytoplasmic shrinkage; MI - mitotic index. 5000 cells for each treatment were analyzed.

Table 2. Cells changes and mitotic index in A. cepa roots submitted to different treatments during the rainy season.

\begin{tabular}{|c|c|c|c|c|c|c|c|}
\hline Treat. & Conc. & LN & LNB & KLN & $\mathbf{K}$ & MN & MI (\%) \\
\hline NC & $\mathrm{dH}_{2} \mathrm{O}$ & $2136^{(\mathbf{b})}$ & $58^{(\mathbf{b})}$ & $63^{(\mathbf{b})}$ & $83^{(\mathbf{b})}$ & $82^{(\text {b) }}$ & $2.94^{(\mathrm{d})}$ \\
\hline EMS & $25 \mathrm{mM}$ & $3649^{(a)}$ & $66^{(\mathrm{a}, \mathrm{b})}$ & $4^{(\mathrm{c})}$ & $6^{(\mathbf{c})}$ & $124^{\text {(a) }}$ & $1.98^{(\mathrm{e})}$ \\
\hline $\mathbf{P A}$ & & $2775^{(\mathrm{c})}$ & $\mathbf{8 2}^{(\mathrm{a})}$ & $25^{(\mathrm{d})}$ & $140^{(a)}$ & $79^{(\mathbf{b})}$ & $6.9^{(a)}$ \\
\hline PB & & $2425^{(\mathrm{d})}$ & $50^{(\mathrm{a}, \mathrm{b})}$ & $155^{(\mathrm{a})}$ & $89^{(\mathbf{b})}$ & $30^{(\mathbf{c})}$ & $6.14^{(a, b)}$ \\
\hline PC & & $2641^{(\mathrm{e})}$ & $58^{(\mathrm{a}, \mathrm{b})}$ & $54^{(\mathbf{b})}$ & $23^{(\mathrm{d})}$ & $112^{(\mathrm{a})}$ & $5.22^{(\mathrm{c})}$ \\
\hline PD & & $2142^{(\mathbf{b})}$ & $24^{(\mathrm{c})}$ & $56^{(\mathrm{b})}$ & $83^{(\mathbf{b})}$ & $11^{(\mathrm{e})}$ & $5.86^{(\mathbf{b}, \mathbf{c})}$ \\
\hline
\end{tabular}

(a), (b), (c), (d) and (e) different letters in the same column differ from each other $(\mathrm{P}<0.05)$ according to the $\chi^{2}$ test; Treat - treatment; $\mathbf{N C}$ - negative control; EMS - positive control; PA - point A; PB - point B; $\mathbf{P C}$ - point $C$; $\mathbf{P D}$ - point D; $\mathbf{d H}_{2} \mathbf{O}$ - distilled water; $\mathbf{L N}$ - one or more large nucleoli; $\mathbf{L N B}$ - large nucleoli and nuclear bud; KLN - karyorrhexis and large nucleoli; K - karyorrhexis; $\mathbf{M N}$ - multiple nucleoli; $\mathbf{M I}$ - mitotic index. 5000 cells for each treatment were analyzed.

The genotoxic activity was detected by observation of chromosome changes that resulted in anomalies such as formation of buds, lagging chromosomes, sticky chromosomes, large nucleoli and multiple nucleoli (Fiskejö, 1985; Ventura-Camargo et al., 2011).

The presence of large nucleoli (Figure $2 \mathrm{~B}$ and $2 \mathrm{G}$ ) is one of the main characteristics of the positive control used in this study. According to Kalinina et al. (2018), plant and animal cells, when subjected to stressful conditions, can develop functional and morphological alterations in the nucleoli. Butorina and Kalaev (2000) reported that the nucleolar activity is the most sensitive parameter to analyze in studies of cytogenotoxicity, with the characteristics most often observed being increased number and size of nucleoli per nucleus.

Analysis of alterations of the size and shape of nucleoli of animal cells is used as an auxiliary tool to distinguish between benign and malignant cells, where the presence of hypertrophied nucleoli with irregular shapes is considered to indicate malignancy (Mäkinen $e t$ al., 1993; Krüger et al., 2000; Montanaro et al., 2008). In plant cells, similar studies have found a relation between the variation in size and shape of nucleoli and the action of genotoxic agents (Arkhipchuk et al., 2000; Ventura-Camargo et al., 2011).

In this study, the water samples collected at all points except point $\mathrm{D}$ in the rainy season caused a significant increase in the number of cells with large nucleoli in relation to the negative control, indicating the presence of agents with genotoxic potential.

The water samples collected at all points during the rainy season also induced variations 
in the number of nucleoli per nucleus (Figure 2I). The interphase nuclei of Allium cepa cells normally each contain two nucleoli, which in some cases can fuse to form a single nucleolus (Lima et al., 2019). The water sample collected at point $C$ induced an increase in the number of nucleoli per nucleus compared to the negative control, while the water samples collected at the other points induced a decrease in the number of nucleoli per nucleus compared to the negative control.

The appearance of multiple nucleoli has been related to the presence of components with genotoxic potential (Imazawa et al., 1995; Lima et al., 2019). Popp and Wachtler (1983) suggested that metabolically inactive cells tend to have fragmented nucleoli, while metabolically active cells tend to have fused nucleoli. Of particular note is that the water samples that led to a reduction in the number of nucleoli compared to the negative control also presented the highest cell division indices (Table 2).

Other genotoxic effects detected in the cells resulting from the samples were the presence of nuclear buds, sticky chromosomes and lagging chromosomes. The samples from all the points during the dry season and from point $\mathrm{A}$ in the rainy season caused a significant increase in the number of nuclear buds (Figure 2C and 2G) compared to the negative control. Nuclear budding is a biomarker of genotoxic events and genome instability. According to Fenech (2006), the buds provide an estimate of the genetic amplification. This theory posits that amplified DNA is selectively concentrated at a peripheral point of the nucleus for expulsion through formation of a bud, which is subsequently detached from the nucleus, leading to the formation of a micronucleus (Fenech, 2006). Lindberg et al. (2007) expanded the theory to include, besides amplified DNA, interstitial fragments, chromosome rearrangement products and anaphase lagging chromosomes as participants in the formation of buds.

Lagging chromosomes (Figure $2 \mathrm{G}$ ) were observed in the cells submitted to the water from point $\mathrm{D}$ during the dry season. The occurrence of this type of alteration suggests the presence of pollutants with aneugenic effects, which act negatively on mitotic fusion, preventing one or more chromosomes from associating with the fibers of the mitotic spindle during anaphase. Those interferences might have been caused by alterations of the microtubules, deformations in the spindle structure or failure of the chromosomes to move toward the poles (Liman et al., 2019).

Another alteration detected during the dry season was the presence of sticky chromosomes (Figure 2 F-G), observed in the cells treated with water from points A and B. Many molecular mechanisms can lead to the phenotype with sticky chromosomes (Liu et al., 2018). Mechanisms that lead to inactivation of the mitotic spindle inhibit the migration of chromosomes to the cell poles, so they tend to condense and adhere to each other, generating sticky chromosomes (Ventura-Camargo et al., 2011). According to Yadav et al. (2019), this adherence can occur due to an increase of the chromosome contraction and condensation or due to depolymerization of DNA and partial dissolution of nucleoproteins, while the results reported by Pizzaia et al. (2019) indicate that the presence of adherence is associated with multiple DNA fragmentation and alterations of microtubules. Irrespective of the mechanism, this change is a sign of the genotoxic effect of an agent, which can induce irreversible cell damage, including death (Ventura-Camargo et al., 2011).

Besides the genotoxic effects, we also detected cytotoxicity in the analysis of the samples collected in both seasons. We observed cells with characteristics similar to karyorrhexis (Figure 2D) in the dry and wet seasons, and cells with cytoplasmic shrinkage (Figure 2H) in the dry season. Alterations like karyorrhexis and cytoplasmic shrinkage are indicators of cells in the death process (Bhagyanathan and Thoppil, 2016; Vijayarathna et al., 2017; Adeyemi and Awoniran, 2019).

Karyorrhexis is a nuclear alteration found in animal cells, characterized by an irregular distribution of chromatin. It can be found in cells that are in the death process by necrosis or 
apoptosis (Tolbert et al., 1992; Thomas et al., 2009). We observed the presence of cells with nuclear changes similar to karyorrhexis, as also reported in another study by our group with meristematic cells of A. cepa (Lima et al., 2016).

The presence of cytoplasmic shrinkage has been reported by other authors investigating meristematic cells of A. cepa roots submitted to treatment with plant extracts. (Bhagyanatham and Thoppil, 2016; Prajitha and Thoppil, 2017). In these works, the authors reported the presence of shrinkage as one of the cytoplasmic changes associated with apoptosis.

We also assessed the cytotoxic potential of the water samples by measuring the mitotic index. The samples from all collection points in the rainy season and from points $\mathrm{A}$ and $\mathrm{C}$ in the dry season induced a significant increase in the mitotic index in comparison with the negative control. An increase of the mitotic index indicates the occurrence of increased cell division, causing uncontrolled proliferation, induced by components present in the samples analyzed. This effect is harmful to cells, since uncontrolled proliferation is the starting point for the later formation of tumors (Hoshina, 2002; Caritá and Marin-Morales, 2008).

The roots submitted to the water samples collected in the dry season presented a higher number of cytotoxic and genotoxic alterations, indicating that the cytogenotoxic potential of the pollutants in the water varies in function of the season of the year, due to an increase in contaminated effluents. Similar results were obtained by other authors (Caritá and MarinMorales, 2008; Oliveira et al., 2011; Gomes et al., 2015).

Therefore, the analyses reported here indicate the presence of pollutants with cytotoxic and genotoxic potential in the water samples collected. These results corroborate the water quality data published by the Rio de Janeiro State Environmental Institute (INEA) in 2017 and 2018. The monitoring carried out by the INEA involves variables considered most representative in relation to water quality, namely dissolved oxygen (DO), biochemical oxygen demand (BOD), total phosphorus (TP), nitrogen and nitrate $\left(\mathrm{NO}_{3}\right)$, potential of hydrogen $(\mathrm{pH})$, turbidity $(\mathrm{T})$, total dissolved solids (TDS), water and air temperature and thermotolerant coliforms. These data are consolidated in a single value, by calculating a water quality index (in Portuguese, $\mathrm{IQA}_{\mathrm{NSF}}$ - Water Quality Index by National Sanitation Foundation). The consolidated water quality bulletins for 2017 and 2018 demonstrated that the water quality at the collection points located in the municipality of Barra do Piraí (Piraí River and Paraíba do Sul River) varied between the poor and medium ranges. Poor IQA ${ }_{N S F}$ values indicate the water is improper for conventional treatment for human consumption, making it necessary to apply more advanced treatment methods (INEA, 2017; 2018).

In this respect, only $60 \%$ of sewage is collected in Barra do Piraí, but even it is not treated. According to the Mid-Paraíba do Sul Basin Committee (CBH-Médio Paraíba do Sul, 2017), this means approximately 1,229 million $\mathrm{m}^{3} /$ year of raw sewage is discharged into the river.

\section{CONCLUSIONS}

The results obtained in this study demonstrate the presence of pollutants with cytotoxic and genotoxic effects in the water collected at all sampling points. Hence, there is an urgent need for further monitoring of sanitation services, in particular treatment of the water for public supply, since the presence of pollutants, many of which are not amenable to treatment with conventional methods, poses a high risk to organisms at different trophic levels, including humans.

\section{REFERENCES}

ADEYEMI, D. O.; AWONIRAN, P. O. Curcuma longa extracts suppress pathophysiology of experimental hepatic parenchymal cell necrosis. Pathophysiology, v. 26, p. 153-162, 2019. https://doi.org/10.1016/j.pathophys.2019.04.002 
ARKHIPCHUK, V. V.; MALINOVSKAYA, M. V.; GARANKO, N. N. Cytogenetic study of organic and inorganic toxic substances on Allium cepa, Lactuca sativa, and Hydra attenuate cells. Environmental Toxicology, v. 15, n. 4, p. 338-344, 2000. https://doi.org/10.1002/1522-7278(2000)15:4\%3C338::AID-TOX10\%3E3.0.CO;2-R

BHAGYANATHAN, N. K.; THOPPIL, J. E. Pre-apoptotic activity of aqueous extracts of Cynanchum sarcomedium Meve \& Liede on cells of Allium cepa and human erythrocytes. Protoplasma, v. 253, p. 1433-1438, 2016. https://doi.org/10.1007/s00709-015-0898-y

BUTORINA, A. K.; KALAEV, V. N. Analysis of sensitivity of different criteria in cytogenetic monitoring. Russian Journal of Ecology, v. 31, n. 3, p. 186-189, 2000. https://doi.org/10.1007/BF02762819

CARITÁ, R.; MARIN-MORALES, M. A. Induction of chromosome aberrations in the Allium cepa test system caused by the exposure of seeds to industrial effluents contaminated with $\begin{array}{llllll}\text { azo dyes. Chemosphere, v. 72, p. } & \text { 722-725, } 2008 .\end{array}$ https://doi.org/10.1016/j.chemosphere.2008.03.056

COMITÊ DE BACIA HIDROGRÁFICA DO GUANDU. Plano de contingência para abastecimento de água (Guandu): relatório final (Produto P6), resumo executivo fevereiro, 2015. Available at: http://comiteguandu.org.br/downloads/plano-decontingencia-resumo-executivo.pdf. Access: 04 Jan. 2019.

COMITÊ DE BACIA HIDROGRÁFICA DO MÉDIO PARAÍBA DO SUL. Atlas da região hidrográfica médio Paraíba do Sul. 2017. Available at: http://www.cbhmedioparaiba.org.br/conteudo/atlas-CBH-MPS.pdf. Access: 04 Jan. 2019.

DE CASTRO E SOUSA, J. M.; PERON, A. P.; DA SILVA E SOUSA, L.; HOLANDA, M. M.; LIMA, A. M. V.; DE OLIVEIRA, V. A.; DA SILVA, F. C. C.; LIMA, L. H. G. DE M.; MATOS, L. A.; DANTAS, S. M. M. DE M.; DE AGUIAR, R. P. S.; ISLAM, M. T.; MELO-CAVALCANTE, A. A. DE C.; BONECKER, C. C.; JUNIOR, H. F. J. Cytotoxicity and genotoxicity of Guaribas river water (Piauí, Brazil), influenced by anthropogenic action. Environmental Monitoring and Assessment, v. 189, n. 6, p. 1-11, 2017. http://doi.org/10.1007/s10661-017-6015-2

DEMANBORO, A. C. Gestão ambiental e sustentabilidade na macrometrópole paulista - bacia do rio Paraíba do Sul. Sociedade \& Natureza, v. 27, n. 3, p. 515-530, 2015. https://dx.doi.org/10.1590/1982-451320150311

FENECH, M. Cytokinesis-block micronucleus assay evolves into a "cytome" assay of chromosomal instability, mitotic dysfunction and cell death. Mutation Research, v. 600, n. 1-2, p. 58-66, 2006. https://doi.org/10.1016/j.mrfmmm.2006.05.028

FISKESJÖ, G. The Allium test as a standard in environmental monitoring. Hereditas, v. 102, p. 99-112, 1985. https://doi.org/10.1111/j.1601-5223.1985.tb00471.X

GOMES, J. V.; TEIXEIRA, J. T. S.; LIMA, V. M.; BORBA, R. H. Induction of cytotoxic and genotoxic effects of Guandu river waters in the Allium cepa system. Revista Ambiente \& Água, v. 10, n. 1, p. 48-58, 2015. http://doi.org/10.4136/ambi-agua.1487

HOSHINA, M. M. Avaliação da possível contaminação das águas do Ribeirão Claro, município de Rio Claro, pertencente à Bacia do Rio Corumbataí, por meio de testes de mutagenicidade em Allium cepa. 2002. 52 f. Monografia (Bacharel e Licenciatura em Ciências Biológicas) - Instituto de Biociências, Universidade Estadual Paulista, Rio Claro, 2002. 
IMAZAWA, T.; NISHIKAWA, A.; TADA M.; TAKAHASHI, M.; HAYASHI, Y. Nucleolar segregation as an early marker for DNA damage; an experimental study in rats treated with 4-hydroxy amino quinoline 1-oxide. Virchows Archiv, v. 426, n. 3, p. 295-300, 1995. https://doi.org/10.1007/BF00191367

INEA. Boletim consolidado de qualidade das águas das regiões hidrográficas do Estado do Rio de Janeiro. 2017. Available at: http://www.inea.rj.gov.br/wp content/uploads/2018/12/Boletim-Consolidado-de-Qualidade-das-\%C3\%81guas-por Regi\%C3\%A3o-Hidrogr\%C3\%A1fica-2017.pdf. Access: 04 Jan. 2019.

INEA. Boletim consolidado de qualidade das águas das regiões hidrográficas do Estado do Rio de Janeiro. 2018. Available at: http://www.inea.rj.gov.br/wpcontent/uploads/2019/01/Boletim-Consolidado-de-Qualidade-das-\%C3\%81 guas-porRegi\%C3\%A3o-Hidrogr\%C3\%A1fica-2018.pdf Access: 04 Jan. 2019.

INEA. Avaliação ambiental do rio Paraíba do Sul: trecho Funil-Santa Cecília - Relatório técnico. $\quad 2010 . \quad$ Available at: http://www.ceivap.org.br/downloads2011/REL\%20INEA\%20AA\%20Funil.pdf. Access: 04 Jan. 2019.

KALININA, N. O.; MAKAROVA, S.; MAKHOTENKO, A.; LOVE, A. J.; TALIANSKY, M. The multiple functions of the nucleolus in plant development, disease and stress responses. Frontiers in Plant Science, v. 9, n. 132, p. 1-19, 2018. http://doi.org/10.3389/fpls.2018.00132

KASPER, N.; BARCELOS, R. P.; MATTOS, M.; BARONI, S. Impact of anthropic activities on eukaryotic cells in cytotoxic test. Revista Ambiente \& Água, v. 13, n. 3, p 1-10, 2018. http://doi.org/10.4136/ambi-agua.2107

KRÜGER, S.; STAHLHUT, M.; MULLER, H. Cell cycle-dependent AgNOR analysis in invasive breast cancer. Analytical and Quantitative Cytology and Histology, v. 22, n.5, p. 358-363, 2000.

LIMA, V. M.; GOMES, J. V.; MATOS, A. F.; PEREIRA, G. L.; LARANGEIRA, M. J. C.; BORBA, H. R. Mangifera indica: Evaluation of the cytotoxic and genotoxic potential of the aqueous extract by the Allium cepa test. World Journal of Pharmaceutical Research, v. 5, n. 5, p. 352-361, 2016. https://doi.org/10.20959/wjpr20165-6207

LIMA, M. G. F.; ROCHA, L. C.; SILVEIRA, G. L.; ALVARENGA, I. F. S.; ANDRADEVIERIA, L. F. Nucleolar alterations are reliable parameters to determine the cyto genotoxicity of environmental pollutants. Ecotoxicology and Environmental Safety, v. 174, n. 15, p. 630-636, 2019. http://doi.org/10.1016/j.ecoenv.2019.03.033

LIMAN, R.; ACIKBAS, Y.; GIGERCI, I. H. Cytotoxicity and genotoxicity of cerium oxide micro and nanoparticles by Allium and comet tests. Ecotoxicology and Environmental Safety, v. 168, p. 408-414, 2019. https://doi.org/10.1016/j.ecoenv.2018.10.088

LINDBERG, H. K.; WANG, X.; JÄRVENTAUS, H.; FALCK, G. C-M.; NORPPA, H.; FENECH, M. Origin of nuclear buds and micronuclei in normal and folate-deprived human lymphocytes. Mutation Research, v. 617, n. 1-2, p. 33-45, 2007. https://doi.org/10.1016/j.ecoenv.2018.10.088

LIU, G.; YE, C. J.; CHOWDHURY, S. K.; ABDALLAH, B. Y.; HORNE, S. D.; NICHOLS, D.; HENG, H. H. Detecting chromosome condensation defects in gulf war illness patients. Current Genomics, v. 19, p. 200-206, 2018. http://doi.org/10.2174/1389202918666170705150819 
MÄKINEN, K.; ESKELINEM, M.; LIPPONEN, P.; NUUTINEM, P.; MARIN, S.; ALHAVA E. Ag-NORs related to flow cytometry, morphometry and prognosis in patients with pancreatic cancer. Anticancer Research, v. 13, n. 1, p. 157-160, 1993.

MARENGO, J. A.; ALVES, L. M. Tendências hidrológicas da bacia do rio Paraíba do Sul. Revista Brasileira de Meteorologia, v. 20, n. 2, p. 215-226, 2005.

MONTANARO, L.; TRERÉ, D.; DERENZINI, M. Nucleolus, ribosomes, and cancer. The American Journal of Pathology, v. 173, n. 2, p. 301-310, 2008. http://doi.org/10.2353/ajpath.2008.070752

NIELSEN, M. H.; RANK, J. Screening of toxicity and genotoxicity in wastewater by the use of the Allium test. Hereditas, v. 121, p 249-254, 1994. https://doi.org/10.1111/j.16015223.1994.00249.x

OLIVEIRA, L. M.; VOLTOLINI, J. C.; BARBÉRIO, A. Potencial mutagênico dos poluentes da água do rio Paraíba do Sul em Tremembé, SP, Brasil, utilizando o teste Allium cepa. Revista Ambiente \& Água, v. 6, n. 1, p 90-103, 2011. http://doi.org/10.4136/ambiagua.176

PRAJITHA, V.; THOPPIL, J. E. Cytotoxic and apoptotic activities of extract of Amaranthus spinosus L. in Allium cepa and human erythrocytes. Cytotechnology, v. 69, p. 123-133, 2017. http://doi.org/10.1007/s10616-016-0044-5

PIZZAIA, D.; NOGUEIRA, M. L.; MONDIN, M.; CARVALHO, M. E. A.; PIOTTO, F. A.; ROSARIO, M. F.; AZEVEDO, R. A. Cadmium toxicity and its relationship with disturbances in the cytoskeleton, cell cycle and chromosome stability. Ecotoxicology, v. 28, n. 9, p. 1046-1055, 2019. http://doi.org/10.1007/s10646-019-02096-0

POPP, W.; WACHTLER, F. Changes in nucleolar structure, number and size in cellular activation and inactivation. Cell and Tissue Research, v. 234, n. 2, p. 377-388, 1983. https://doi.org/10.1007/BF00213775

THOMAS, P.; HOLLAND, N.; BOLOGNESI, C.; KIRSCH-VOLDERS, M.; BONASSI, S.; ZEIGER, E.; KNASMUELLER, S.; FENECH, M. Buccal micronucleus cytome assay. Nature Protocols, v. 4, n. 6, p. 825-837, 2009. https://doi.org/10.1038/nprot2009.53

TOLBERT, P. E.; SHY, C. M.; ALLEN, J. W. Micronuclei and other nuclear anomalies in buccal smears: methods development. Mutation Research, v. 271, p. 69-77, 1992. https://doi.org/10.1016/0165-1161(92)90033-I

VENTURA-CAMARGO, B. C.; MALTEMPI, P. P. P.; MARIN-MORALES, M. A. The use of cytogenetic to identify mechanisms of action of an azo dye in Allium cepa meristematic cells. Journal of Environmental \& Analytical Toxicology, v. 1, n. 3, p 1-12, 2011. https://dx.doi.org/10.4172/2161-0525.1000109

VIJAYARATHNA, S.; CHEN, Y.; KANWAR, J.R.; SASIDHARAN, S. Standardized Polyalthia longifolia leaf extract (PLME) inhibits cell proliferation and promotes apoptosis: The anti-cancer study with various microscopy methods. Biomedicine \& Pharmacotherapy, v. 91, p. 366-377, 2017. http://dx.doi.org/10.1016/j.biopha.2017.04.112

YADAV, A.; RAJ, A.; PURCHASE, D.; FERREIRA, L. F. R.; SRATALE, G. D.; BHARAGAVA, R. N. Phytotoxicity, cytotoxicity and genotoxicity evaluation of organic and inorganic pollutants rich tannery wastewater from a common effluent treatment plant (CETP) in Unnao district, India using Vigna radiata and Allium cepa. Chemosphere, v. 224, p. 324-332, 2019. https://doi.org/10.1016/j.chemosphere.2019.02.124 